\title{
A Comparative World-Systems Analysis of Settler Colonies in the Hispanic and Anglo Realms
}

GEOFF BERTRAM

\section{Introduction}

The term 'settler economies' refers to a distinctive group of societies formed and dominated by white European migrants in the nineteenth and early twentieth centuries. In sharp contrast to the colonial experience of more densely populated tropical areas, these temperate-latitude societies were clustered near the top of the world income distribution at about 1900. They had risen to this status by explosive economic growth over a few decades within the nineteenth-century world economy. This was an era of growing divergence between rich and poor economies, when most colonial territories were on the losing side as components of a global periphery ensnared in the 'Great Divergence' of the world economy that occurred between about 1800 and the late twentieth century. ${ }^{1}$

On large land areas in the tropics, where pre-existing agrarian societies with relatively dense populations were subordinated to colonial rule, and where endemic diseases deterred European settlement, colonies of exploitation were the norm. Here, exports of high-value commodities were produced by large enterprises with an increasingly capitalist character (though in the early stages there was widespread use of slave labour, quasi-feudal service tenure, and various forms of forced labour). Insofar as those colonies yielded an economic surplus, colonial institutions were designed to capture a substantial part of that surplus to be transferred to the metropolitan economies, which were thus in a sense parasitic on their colonial possessions.

In the temperate latitudes, pre-colonial populations and societies were pushed aside or eliminated to open space for settlement by European migrants in a relatively benign disease environment. The resulting 'settler colonies' dominated North America, Australia, New Zealand and Siberia; they formed an important component of South Africa and evolved from the previous Spanish colonial regimes in the Southern Cone of South America (Argentina, Uruguay and Chile). The characteristic feature of these settler colonies, both formal and informal, ${ }^{2}$ was that they were parasitic on the metropolitan economies rather than the other way round. They used 
economic surplus transferred from the metropolis to build up high-income modern economies on the outer geographical fringes of the world system. The resulting socio-economic formations have been variously described as 'dominion capitalism' ${ }^{3}$ and 'settler capitalism'. ${ }^{4}$

It is common to distinguish between Hispanic and British settler economies. Angus Maddison ${ }^{5}$ calls settler economies in general 'neoEuropes' with the United States of America (USA), Canada, Australia and New Zealand grouped in a subset called 'Western offshoots'. James Belich ${ }^{6}$ classifies the Hispanic Southern Cone countries as 'adopted dominions' in contrast to the Anglo societies.

The driving force of the nineteenth-century world economy was British industrialization (followed by a sequence of similar industrialization processes in Western Europe and the north-eastern USA) but the settler economies were not industrial powerhouses. They were engaged primarily in the production and export of primary commodities, and their historical distinctiveness lies in the fact that they became rich by this route. This experience was not repeated until the rise of the Middle Eastern oil economies in the second half of the twentieth century.

Five agrarian export economies of the global periphery - New Zealand, Australia, Argentina, Uruguay and Canada - are the ideal-type examples of the settler economy model. Three other former colonies dominated by European immigrant settlers in the late nineteenth century - South Africa, Chile and the USA west of the Appalachians - fit the general pattern, but with important qualifications. In Chile and South Africa mining exports crowded out agricultural and pastoral ones, resulting in export-enclave economic structures and lower per capita incomes than in the agrarian cases; while in South Africa white settlers were always a minority exercising control over a numerically superior non-white population, leading to a dual society and economy. In the USA, the settler-agrarian experience in the nineteenthcentury mid-west was harnessed to an authentic industrial capitalism in the northeast within a federal nation-state political unit, with the result that the aggregate statistical and historical record is a hybrid.

These eight economies all shared to varying degrees in what could be called the 'settler economy golden age' between 1890 and 1930. If the United States settler-capitalist economy is considered as restricted to the regions west of the Appalachians and Great Lakes, all were peripheral to the industrial revolution and geographically far from its central locus, yet shared the living standards, political systems and cultures of the global core.

Having converged by 1900, after 1930 the settler economies began to diverge again. The USA pulled away to become an industrial superpower, while the Hispanic Southern Cone and South Africa fell behind in relative 
terms. The British dominions - Canada, Australia and New Zealand held - together until the 1970s, but thereafter also began to diverge.

Figure 1, reproduced from Bertram, ${ }^{7}$ shows those diverging post-1900 trajectories of per capita Gross Domestic Product (GDP) in seven of the settler economies (the US was not included in this chart). The question of why, having started the century as a closely bunched 'convergence club', the settler economies then diverged, has attracted substantial literature, mostly focused on the reasons for relative 'failure' of the Hispanic settler economies.

Writers such as Kirby, Senghaas and Finch ${ }^{9}$ have drawn attention to the greater inequality of landholdings in the Southern Cone of Latin America, compared with the prevalence of medium-sized family farms in the British dominions and the mid-western USA, and have linked this to lower technological dynamism in the Hispanic cases. Others frame the issue more widely in terms of greater income inequality in the Hispanic versus the Anglo societies, ${ }^{10}$ or the greater political instability, weaker legitimacy of the state, and greater role of the military in politics in the Hispanic realm than in the Anglo dominions. Mitchell, ${ }^{11}$ for example, suggests the Argentine state was unable to consolidate an efficient tax system and so faced fiscal weakness. Rock ${ }^{12}$ attributes Argentina's twentieth century travails to the three-century inheritance of Hispanic institutions which, he argues, blocked a transition to successful economic diversification and constructive response to crises of the export economy; land tenure was only one symptom of

Figure 1. Seven Settler Economies Per Capita GDP, five-year moving averages, $1900-2000$.

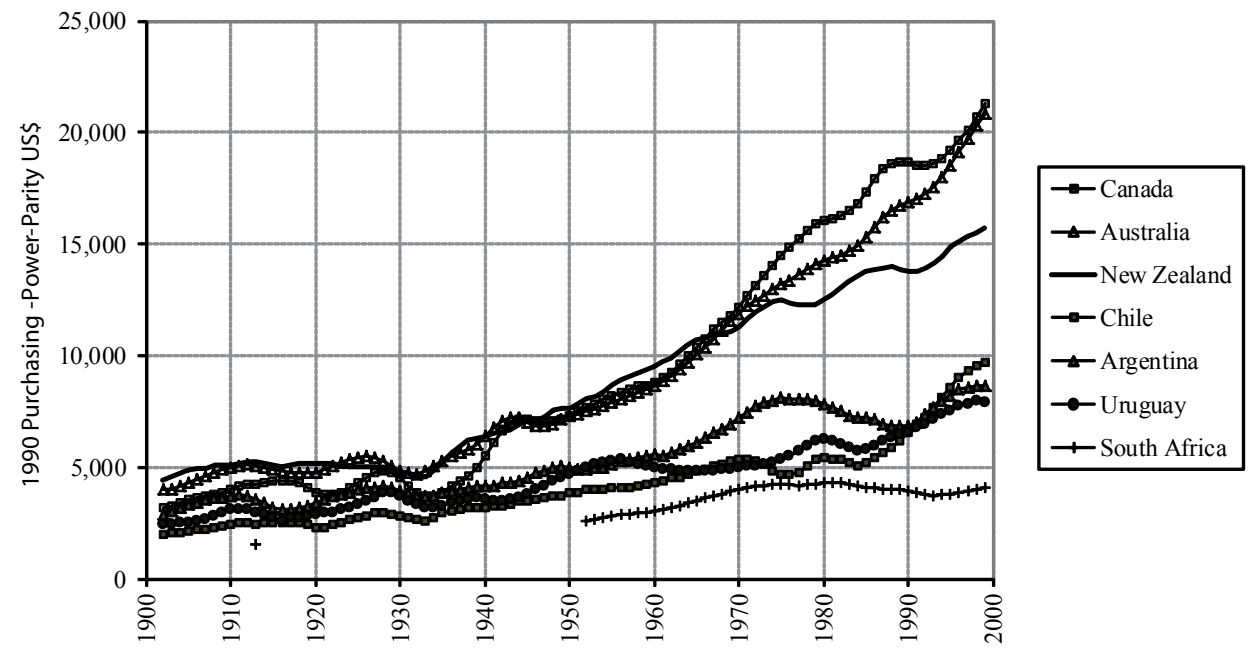


the more general issue in this view. Other analysts contrast policy making content and effectiveness in the leading and the lagging settler economies - particularly during the general era of import-substituting industrialization and attempted income redistribution towards labour from 1930 to 1970. At this time, Peronism in Argentina and the flagging battlista programme in Uruguay contrasted with relatively successful policy performance in the British dominions and the USA.

An alternative line of explanation focuses less on the internal structure and dynamics of individual settler societies and more on forces at work in the global economy. Bertram ${ }^{13}$ for example, offers the following account of the start of the divergence process:

Convergence among these settler economies ended with the Depression, with the 1932 Ottawa conference marking the watershed. At Ottawa the British dominions secured a defensive victory for their pastoral exports at the expense of the Latin Americans, on the back of which they were able to successfully diversify their economies under strong democratic institutions over the following three decades. Having held their market access, the three British dominions fought with Britain in the Second World War, adapted successfully to the Bretton Woods era of macroeconomic policy and then pulled away to double their per capita income by 1960. The 'Southern Cone' countries (Argentina, Uruguay and Chile, located in the southern tip of South America) faced export market closure in the 1930s, few gains from the Second World War and its aftermath, and growing political stresses as economic growth lagged. All three had fallen prey to military coups by the mid 1970s. Only at the end of the 'lost decade' of the 1980s did they return to sustained growth under democratic institutions. In the interim, the Second World War had driven a deep wedge between the British dominions and the USA, which had by that time become the global economy's industrial superpower. The three dominions therefore shared a similar trajectory, parallel with the USA, until the late 1960s. Thereafter Canada and Australia pulled away from New Zealand.

In this account what was specific to the Anglo societies was less their domestic institutions and production systems than their degree of integration with and political closeness to the dominant world-system power of the time, Great Britain. The 1932 Ottawa conference was the high point of British Imperial Preference, with the British dominions granted ongoing access to the United Kingdom (UK) market for meat, dairy products and wool while the Hispanic Southern Cone economies were subjected to quotas.

This approach frames the differential impact on settler economies of the Great Depression in terms of whether each society's nineteenth-century 
history had been one of formal or informal incorporation into the British Empire. However, it probably abstracts too much from the particular domestic forces and histories of the societies under consideration. British preference for the dominions over the Southern Cone was not simply a matter of sentiment; it acknowledged the strengths of the dominions as technologically progressive export producers and hard bargainers at the conference table.

To understand how shifting conjunctures in the world system produce differing outcomes for particular societies on the global periphery, it is necessary to trace the interaction of internal and external dynamics case by case. Global conjunctural forces sometimes were strong enough to fully determine synchronized outcomes across all the settler economies, but at other times came to bear selectively, or were too weak to counteract individual societies' internal dynamics, historical legacies and policy environments. Dependent development was (and is) a two-sided, not a onesided, process.

\section{Convergence and divergence in economic theory}

Mainstream economics, including modern growth theory, is prone to a particularly strong and deterministic view of the evolution of the world economic system. In the long run, all economies are predicted to converge to the technology and income level of the most advanced. This follows from the logic of competitive market forces. Labour, capital and technology should flow, in response to economic incentives, to where they can earn the highest returns, and this process should equalize the return to each factor of production, at the margin, across the world economy. Similarly, under competitive conditions, goods and services will tend to be produced and exchanged according to comparative advantage, and this also should tend to equalize factor prices, hence incomes, across the world system. ${ }^{14}$ These propositions were familiar to the Classical economists of the nineteenth century: Ricardo (1814) ${ }^{15}$ worked out the implications of equalization of the profit rate across sectors, and $(1817)^{16}$ developed the theory of comparative advantage. The international prediction of factor price equalization through the operation of market forces was clearly stated by Ricardo's follower John Stuart Mill:

If to carry consumable goods from the places where they are superabundant to those where they are scarce, is a good pecuniary speculation, is it not an equally good speculation to do the same thing with regard to labour and instruments? The exportation of labourers and capital from old to new countries, from a place where their productive power is less, to a place where it is greater, increases by so much the aggregate produce of the labour and capital of the world. It adds to the joint wealth of the old and the new country, what amounts in a short 
period to many times the mere cost of effecting the transport. There needs be no hesitation in affirming that Colonization, in the present state of the world, is the best affair of business. ${ }^{17}$

Ricardo's other great successor economist, Karl Marx, also saw equalization of the profit rate as a fundamental driver in unifying the word as a single capitalist system:

The need of a constantly expanding market for its products chases the bourgeoisie over the entire surface of the globe. It must nestle everywhere, settle everywhere, establish connexions everywhere. . . The bourgeoisie, by the rapid improvement of all instruments of production, by the immensely facilitated means of communication, draws all, even the most barbarian, nations into civilisation. The cheap prices of commodities are the heavy artillery with which it batters down all Chinese walls, . . It compels all nations, on pain of extinction, to adopt the bourgeois mode of production; it compels them to introduce what it calls civilisation into their midst, i.e., to become bourgeois themselves. In one word, it creates a world after its own image. ${ }^{18}$

Marx, however, left open the issue of whether global equalization of rates of return to factors of production other than capital would occur, given the active agency of capitalist elites in using institutional mechanisms and state power to shape emerging production systems in favour of capital, and more particularly in favour of metropolitan capital. The Anglo settler economies attracted Marx's attention precisely because of the inability of metropolitan capital to keep migrant labour on the Anglo frontier separated from land and hence to equalize the 'rate of exploitation' between core and periphery in these cases. Elsewhere in the colonial realm, production relations were more successfully skewed against labour by slavery, tax and land policies, and the successful use of force. In Marx's analytical approach, the institutional setup of global and local labour markets dictated which modes of production became established on the periphery, and hence (potentially) the long-run global distribution of income. Neither convergence nor divergence of income levels across countries was preordained in this framework. Marx thus left something of an analytical vacuum to be addressed a century later by Baran ${ }^{19}$ and then by dependency and world-system theorists.

Returning to mainstream economic theory, the expectation that market forces must tend to equalize the distribution of income across the world economy has remained strong. The standard Solow ${ }^{20}$ neoclassical growth model predicts that in a world with a uniform technology, operation of market forces should tend to make all economies converge to long-run steady-state levels of relative income per capita, which should differ only insofar as savings rates and population growth rates differ. The apparent 
failure of international factor markets to exhibit strong convergence presents a theoretical 'puzzle' to which only ad hoc empirical solutions seem to be available within the neoclassical paradigm. ${ }^{21}$

Economic historians have long been conscious of the fact that the past two centuries have witnessed divergence rather than convergence between core and periphery, ${ }^{22}$ but have mostly stuck with the intuitive expectation that in the long run 'catch up' will be the norm. ${ }^{23}$ Rostow $^{24}$ formulated a model in which, one after another, individual economies break free of 'tradition' and enter upon rapid growth to catch up to US living standards. Lucas ${ }^{25}$ presented the catch-up story in modern mathematical form, with the same predicted outcome. Divergence in this view is simply a temporary historical phase; if we wait long enough, all economies must in due course catch up and settle in a converged group with differences attributable only to savings and demographics. The recent rise of China and India, and signs of catch up by sub-Saharan Africa, fit this story.

The difficult issue for the mainstream paradigm is to identify the factors which hold economies back from taking off and catching up. Typically the literature appeals to retarding elements in the backward economies - traditional attitudes, obstructive institutions, corruption, monopoly, in short what economists call 'market imperfections'; the removal of which should clear the way for more rapid growth. In this context, a puzzle for the mainstream is the empirical evidence of continuing divergence in the half century since decolonization and the rise of globalization, which might have been expected to remove or reduce the market imperfections inherent in colonial rule.

The empirical fact of divergence rather than convergence left the way open for an alternative theoretical approach to global development, emphasizing the long-run division of the world economy between an industrializing capitalist core and a periphery of less developed economies held in an essentially dependent relationship to the core. From dependency theory in the 1960 and 1970s, this approach evolved into world-system theory in the 1970s and 1980s. Rather than seeking explanations for the relative backwardness of the periphery in terms of social structures, institutions and national histories of the periphery countries, the world-systems approach started from the notion of an international division of labour in which subordinate roles are assigned to periphery economies by the system, not by their own merits or demerits. In the hands of writers, such as Wallerstein and Amin, this tended to become a story of rich core and poor periphery, with the unequal distribution of the global product attributed to the capitalist system itself.

The great attraction of this position was that it rejected the idea of a universal, unique evolutionary path that all economies must follow through time, terminating in a converged world after all have caught up. Dependency 
theory argued that the logic of the international division of labour, in a world where capital accumulation was driven from the core, was one of unequal exchange and divergent outcomes for income per capita. Underdevelopment itself was modelled as an outcome of the dependent-development process rather than a simple failure to develop. World-systems theory sought to identify the processes through which the evolving world division of labour was able to create and then reproduce inequality across the global economy.

The country-by-country detail, however, revealed difficulties for any dependency and world-systems formulations that hoped to abstract completely from national considerations and attribute the periphery economies' condition entirely to their peripheral status. Senghaas'26 systematic comparative review of the economic histories of the periphery made clear the need to acknowledge the significance of genuine agency within each peripheral society as it engaged with the wider global system. In the process, Senghaas reduced the scope for deterministic outcomes to flow from the global division of labour on its own.

Equally problematic was the issue of where the settler economies fitted into a world-system scheme of analysis, given their geographic location on the periphery yet their resemblance to the core in terms of incomes and culture. Senghaas placed distant peripheral economies, such as New Zealand, into the same analytical categories as smaller European economies such as Denmark, implicitly locating them within the world core regardless of geography. But just reclassifying rich economies out of the periphery and into the core did harm rather than good to world-systems generalizations about the necessary consequences of peripheral status.

Denoon treated the settler economies as a distinct category, neither core nor periphery, characterizing 'settler capitalism' as a special process of dependent development and toying with the issue of whether the economies possessed a distinctive mode of production:

[S]ettler societies possessed a dynamic that differed from that of most of the tropical world, where dense agricultural populations survived the colonial intrusion. Equally, they differed from the metropolitan societies from which they derived. . . . In a preliminary way, it is proposed that these societies practised a mode of production to be termed 'settler capitalism. ${ }^{27}$

Denoon's descriptive list ${ }^{28}$ of seven characteristic features of his settler capitalisms, however, fell short of amounting to a mode of production in the traditional sense, as he himself acknowledged. The list, in summary, was:

- Each society began as a garrison-outpost of one European empire or another; 
- There was no exploitable indigenous community strong enough to sustain a stratum of conquering settlers, so pre-existing modes of production were replaced by the settler influx;

- High land-labour ratios led to early adoption of frontier pastoralism, whose needs determined the rest of the economic structure;

- Heavy reliance on inflows of labour and capital did not translate to subservience to Britain in political matters;

- Political relative autonomy did not result in economic diversification; rather to 'unforced dependence' upon the export of a few specialized staples;

- This specialization went hand in hand with both radical institutional innovation and ruthless suppression of dissent from the ruling model;

- The demise of peasantry was "more abrupt ... than occurred in ost other parts of the world'.

Only slightly better focused was the development by Ehrensaft and Armstrong ${ }^{29}$ of their 'dominion capitalism' model which summarized the features of the settler economies and, in the process, singled them out as a special case. In the process, the deterministic identification of dependent development with income divergence had to be set aside. World systems analysis was thus made more realistic, but less clear in its predictions. Global forces working through the capitalist market system remained the central focus, but a range of essentially ad hoc devices were required to explain the detail of real-world history.

In this situation, it is worth looking again at episodes of actual convergence and divergence, in the hope of clarifying the balance of explanation amongst global forces operating regardless of national circumstances, national or local agency in the face of the challenges and opportunities thrown up by the evolving world system and elements of path-dependence in the histories of countries and regions.

There are some well-known cases. Most celebrated are the convergence processes amongst states within the USA and prefectures in Japan over the past two centuries, and amongst the OECD economies since World War II. ${ }^{30}$ Cashin $^{31}$ found evidence of convergence across the colonies of Australasia (including New Zealand) during the nineteenth century when they were closely linked together, replaced by divergence in the twentieth century. Greasley and Oxley ${ }^{32}$ concur. Perhaps especially relevant in the context of a discussion of settler economies, there is evidence from smallisland economies around the world of economic convergence of 'dependent' entities to the income levels of their metropolitan 'patrons' - a convergence that is dramatically weakened by sovereign independence and strengthened by political integration with the patron. ${ }^{33}$ 
Using Maddison's long-run dataset, Figure 2 shows the per capita GDP of the eight settler economies relative to that of the UK (the core of the nineteenth-century world system). The picture speaks for itself. The nineteenth century started with the economies widely dispersed and on divergent trajectories, so far as can be estimated. In 1820 we see New Zealand at the bottom, with Maddison's subsistence level of $\$ 400$ per year per capita; Australia a little above that due to its early settlement; the Iberian economies of the Latin American Southern Cone probably a little higher (though Maddison's data for them does not extend back before 1870); Canada higher again; and the USA heading the group with a per capita income already three-quarters the British level, as the north-east industrialized. There is then a radical convergence of Australia and New Zealand to equal Britain by the 1870 s, followed by a somewhat later surge first by Uruguay (hard to date in the absence of data) and then in concert in the 1890 s by Canada, Argentina, and Chile (Maddison's GDP data for South Africa were too sparse to include it in this chart).

For four decades from the 1890s the convergence outcome held, with the Iberian cases apparently settling to a lower steady state than the Anglo ones. Then the glue failed and the economies began to drift apart again. The USA pushed on to economic superpower status; Canada and Australia consolidated their position just above the UK from 1950 on; New Zealand stayed with those two until the 1960s, then began to drift down; the Iberian settler economies were all on a divergent track from the late 1930s.

Outside that golden age of 1890-1930, Figure 2 seems to suggest that the seven economies have been on long-run divergent tracks for the past two or three centuries, interrupted by the remarkable convergence at the end of the nineteenth century. It is as though a corset had suddenly been tightened around the group, pulling them together into a narrow corridor in which they were held until the Great Depression. Then the corset was released and the economies slumped back onto their long-run paths. The implication would seem to be that world-system convergence dynamics do not apply consistently over the long haul and, indeed, that in the long run, the trajectories of individual economies are largely determined by factors specific to each economy, subject to global market forces and technological trends that may be sufficient to generate underlying 'conditional convergence' but are not strong enough to prevail in absolute terms. Only at certain historical moments, for certain groups of economies, do world-system forces strengthen to the point where they overwhelm the divergent tendencies imparted by national characteristics and path dependence. The settler capitalist economies exhibit, therefore, first their own great convergence, then a stable converged 'golden age', and then a great divergence. These three periods frame the discussion in the remainder of the paper. 


\section{Nineteenth-century convergence}

As noted at the outset, what was distinctive about the settler economies was that they rode the nineteenth-century upswing of the winning side of the global great divergence without an internal dynamic approximating the industrial revolution in the core of the capitalist world system. In one simple version of the story, they were like carriages in an export-led train, pulled along behind the capitalist locomotive of the British economy and (to a lesser extent) the other components of the world-system core. The crucial linkage was provided by exports of the great staples - wheat, wool, meat, dairy products - produced by migrant settler communities transplanted into land-abundant open space on the geographic periphery, mainly from Britain but also from other European labour exporters including Scandinavia, Italy and Spain. ${ }^{35}$

It is true that the export-driven staples story fits well the structure and dynamics of settler economies between 1890 and 1930, when the agrarian five - New Zealand, Australia, Argentina, Uruguay, and Canada - provided

Figure 2. Per Capita GDP relative to UK, Seven Settler Economies, 1700-2009.

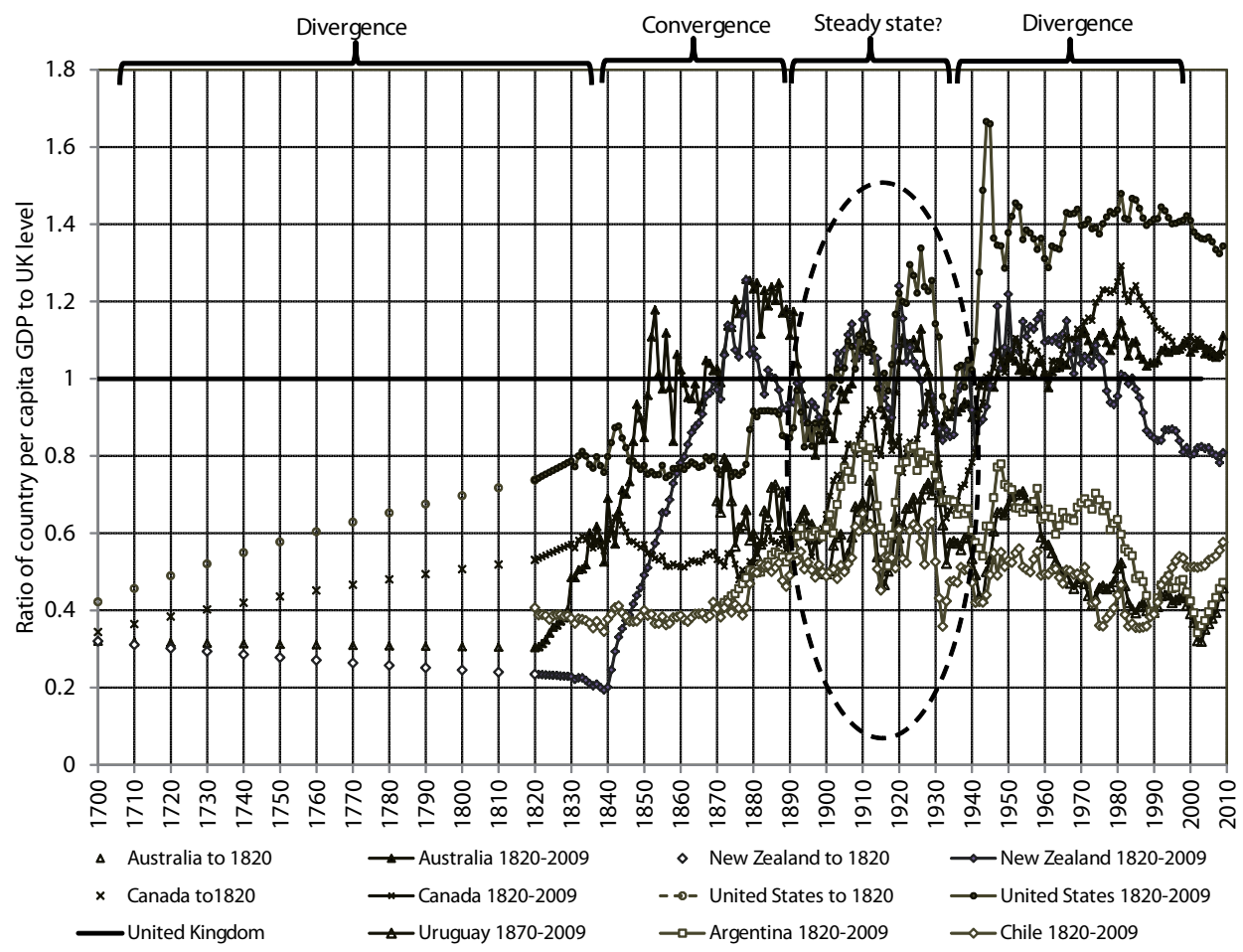


classic examples of successful export-led development. But the process of mass migration to high-income areas of settlement had been well underway - at least in the Anglo world - for some decades prior to the emergence and consolidation of the export-led model, as Belich ${ }^{36}$ has recently documented in detail, following in the footsteps of Denoon, ${ }^{37}$ Taylor and Williamson ${ }^{38}$ and others.

It is necessary therefore to distinguish between the initial emergence of settler socioeconomic formations on the periphery, and the subsequent discovery that these formations, once established, were well adapted to servicing the booming demand for staples export supply that emerged in the world system of the later nineteenth century. One can think of the settler story in terms of economic response to two successive, and separable, market openings.

\section{Stage One: Factor market opening, mass migration, and the mode of production in the colonies}

What happened in the first stage was the opening to European (especially British) peoples of a key offshore factor market for land. Falling transportation costs combined with physical access to relatively sparsely populated landabundant spaces whose indigenous inhabitants had been, or were in the process of being, cleared out of the way by military might and European diseases, triggered massive migration of both capital and labour, which were in surplus supply relative to scarce land within Britain. The mass migration process was underway by the late 1820 s and gathered momentum over the following half-century. Its logic was the logic of mainstream economic theory and factor-price equalization: the mobile factors, land and capital, moved to combine with the immobile factor, land.

In Belich's account (Chapters 5-6) ${ }^{39}$ the crucial settler dynamic began with the emergence of what he terms 'explosive colonization' - the mass transfer of migrants from metropolis to periphery. Schemes of industrial-scale colonization date from the 1820 s and 1830 s and were driven as much from below (the emergence of a mass willingness and desire to emigrate) as from above (the entrepreneurs and their 'booster industry'). Substantial numbers of migrants had moved to the far ends of the earth before the emergence of any clearly-defined market demand for staples that they might produce for export back to the metropolis. The settler notion of 'little Englands' was not a prediction of the emergence of staple-export economies.

The motivating force for migration in this early stage seems to have been the desire of individuals to better themselves and their families. The lands of new settlement held out initially the hope of self-sufficiency at a good standard of living without the need to enter into an exploitative wage-labour relation: an upwards escape for working-class people from the constraints 
of the emerging capitalist mode of production in Britain. The escape was feasible physically because of British political and military hegemony over land-abundant temperate zones of the globe where the disease risk was relatively low. It became feasible economically when ocean transportation rates fell for migrants - partly because of technical advances, partly because of the need of whalers, and shippers of other extractive-industry products from the far periphery, to find back-loads for their ships, and partly because of the availability of direct fare subsidies from colonizing interests in Britain.

The fact that Belich's explosive colonization preceded, chronologically, the emergence of well-defined markets for export staples produced in the periphery is important. In place of explanations that start from the growing metropolitan demand for food and raw materials as the industrial revolution took off, and then account for settler capitalism as a process driven from the imperial demand side by export prospects, the evidence points to a process driven more on the supply side of the British economy: escape from poverty and exploitation in the metropolitan labour market by exit from the metropolis itself, as soon as a viable escape hatch opened. As the nineteenth century progressed, demand-side forces progressively asserted themselves and reinforced the mass migration, but they do not account for its initial take-off.

As Taylor and Williamson note, ${ }^{40}$

The convergence power of free migration, when it is tolerated, is likely to be substantial given the late nineteenth-century evidence. Cheap labour did not wait for foreign capital to seek it out; it did not ignore distant immobile natural resources that beckoned it to move; it did not wait for human capital accumulation or spillovers to initiate catching up at home; it just went in search of higher wages elsewhere. Convergence explanations based on technological or accumulation forces in closedeconomy models miss this point. The millions on the move in the late nineteenth century did not.

The migrant settlers had, thus, a substantial degree of autonomy and agency. This accounts for several of the features often noted in settler-economy accounts: a degree of self-conscious independence from metropolitan dictation in policy and constitutional matters, a willingness to experiment with institutional innovations (including, for example, partial welfare-states in the early twentieth century in societies as otherwise divergent as New Zealand and Uruguay); and wherever possible, the pursuit of self-sufficiency and self-employment in preference to fully-capitalist wage labour.

When seen as a static matter of resource allocation, the mass migrations of the nineteenth century were a one-off process of market equilibration, 
which would be expected to proceed until the returns at the margin to land, labour and capital had been equalized across the world market system. There was more to it than that, in several ways. Firstly, the settler process was not simply a static resource reallocation. It involved dynamic and structural developments which would run through at least the following century. Second, so long as population growth rates and savings rates continued to differ from country to country, new opportunities for profitable transnational relocation of capital and labour would be continuously reproduced over time, so that final equilibrium was always a moving target. Finally, global factor markets could perform their full equilibrating function only so long as they operated in a reasonably unconstrained market environment. From the First World War onwards, both labour movement and capital flows became subject to increasingly stringent restrictions, which reversed the great market opening of the nineteenth century and foreclosed the theoretically-possible further equalization of incomes across the world economy by means of factor movements.

In terms of economic structure and dynamics, the settler-mass-migration era in the mid-nineteenth century saw the emergence of frontier economies in which the 'mode of production' was not a simple transplant of the social relations prevailing in the capitalist core. Migrant settlers brought with them the education levels, technology and aspirations for income and social justice, of their source countries, and were motivated to move by the perceived opportunity to secure better returns on those human-capital assets, as well as on their raw labour power. Once arrived, they were in an environment where the opportunity cost of their labour power was measured in terms of the level of income they could secure as self-employed agricultural operators. The resulting market wage rate, measured in terms of consumable wage goods, was far above the market wage back in the core economies, where land scarcity continually tended to push up wage-goods prices, and capitalist wage-labour relations of production had to be accepted as the best deal on offer for landless workers.

The relative abundance of land on the new frontiers produced a distinctive institutional setup in agriculture wherever an institutional framework to monopolize land had not been entrenched before the settlers arrived. In Chapter 33 of Volume One of Capital, Marx, ${ }^{41}$ criticizing Wakefield's colonization schemes, saw clearly how the equilibrium migrant income would be determined on a frontier where land access was unrestrained, and the implication for the labour market:

In Western Europe . . . the capitalist regime has either directly subordinated to itself the whole of the nation's production, or, where economic conditions are less developed, it has at least indirect control of those social layers which, though they belong to the antiquated 
mode of production, still continue to exist side by side with it in a state of decay ... It is otherwise in the [settler] colonies. There the capitalist regime constantly comes up against the obstacle presented by the producer, who, as owner of his own conditions of labour, employs that labour to enrich himself instead of the capitalist. The contradiction of these two diametrically opposed economic systems, manifests itself here practically in a struggle between them. . . . A Mr. Peel . . . took with him from England to the Swan River district of Western Australia means of subsistence and of production to the amount of $£ 50,000$. Mr. Peel even had the foresight to bring with him, besides, 3000 persons of the working class, men, women, and children. Once arrived at his destination, 'Mr. Peel was left without a servant to make his bed or fetch him water from the river.' Unhappy Mr. Peel, who provided for everything except the export of English modes of production to Swan River! . . . The expropriation of the mass of people from the soil forms the basis of the capitalist mode of production. The essence of a free colony ... consists in this, that the bulk of the soil is still public property, and every settler on it can therefore turn part of it into his private property and his individual means of production, without preventing later settlers from performing the same operation. This is the secret of ... the prosperity of the colonies. ... In the colonies ... the absolute numbers of the population increase much more quickly than in the mother country, because many workers enter the colonial world as ready-made adults, and still the labour market is always understocked . . . Today's wage labourer is tomorrow's independent peasant or artisan, working for himself ... [As a result] the degree of exploitation of wage-labour remain[s] indecently low.

Marx correctly foresaw the high-wage environment that was implied by the combination of abundant land and settler access to possession and use of that land, but he did not foresee that the migrant settler, once emancipated by access to abundant land, would rise above the status of artisan or peasant. What emerged instead of a peasantry, wherever local institutions allowed, was the family farm as a key agricultural producing unit.

The family farm, established by literate migrants with experience of industrial capitalism and of free markets, was (and is) non-capitalist in the essential sense that it organizes its labour force by non-wage incentives. But it is different from the usual conception of a peasant enterprise in the totality of its commitment to specialization, and in its reliance on the sale of specialized output on commercial markets for all or most of its income, with subsistence production relegated to marginal importance. In settler economies it emerged as an economically efficient means of recruiting, holding and managing the agricultural or pastoral labour force. Once established, the 
family farm was able for most of the twentieth century to hold its own against competition from capitalistically-organized corporate farming. In Australia, New Zealand, the USA and Canada the family farm proved capable of rapid technical change, dynamic investment performance, and radical institutional innovation on the boundary where the non-capitalist production mode was articulated with the wider capitalist world. Marx underestimated the extent to which a petty-bourgeoisie could be technologically progressive.

Not all the settler economies, however, had the family farm at the centre of the relations of production in agriculture. In all settler societies, the second half of the nineteenth century witnessed a confrontation between two alternative production systems: great estates and owner-operated family farms. Marx had been correct in predicting that if it were possible to separate the mass of settlers from access to land, and thereby force them into seeking employment from a group which held a monopoly of the non-labour means of production (land and capital), then the evolution of economic structure would take a different course. In the British colonies of settlement, as already noted, land had not been successfully locked up prior to the arrival of the settlers, and any attempt in one colony to restrict access to new land, or to put a heavy price on it as a means of extracting surplus from the settlers, would simply cause the migration flow to divert to other Anglo societies where no such constraints applied. The settler process thus proceeded under workably competitive conditions. Political pressure from the established family-farmer class for the breakup of large estates as a means of making more land available for intensive settlement then drove Anglo policy.

But Marx did not study the Hispanic settler economies, where access to land for the mass of migrants was foreclosed by pre-existence of large estates and control of politics by elites entrenched during three centuries of colonial rule by Spain. Hence he did not draw the contrast between the outcome of frontier settlement under permissive Anglo institutions and the very different rural societies of Uruguay and Argentina.

The settlement of the pampas of Argentina and Uruguay began with the assertion of property rights over large areas of land, initially by caudillos with mini-armies of followers, leaving the estancia as the main form of rural property by the nineteenth century. Land ownership was formally enforced in the 1860s and 1870s by wire fencing (effectively, an enclosure process reminiscent of what had earlier happened in Britain). ${ }^{42}$ In Argentina, the wool boom of the 1850 s was driven by immigrants but did not lead to the emergence of a class of independent owner-farmers; on the contrary most sheep farmers were tenants, and government policies on the sale of large land blocks under presidents from Rosas on led to consolidation of the latifundio (great estate) as the dominant rural institution at the same time as immigration intensified. ${ }^{43}$ As Rock summarizes the situation, 
'European immigrants to Argentina were . . . welcomed as farmers, but found themselves increasingly enjoined from land ownership.' ${ }^{44}$

Instead, migrants became sharecroppers, tenants, shepherds, or seasonal labourers - or joined the urban labour force as artisans or wage workers. ${ }^{45}$ Political pressure to break up large estates was as present in the Southern Cone as it was in the Anglo settler colonies, but it was unsuccessful. Wire fencing - the main technology for enclosure in settler economies - defined and protected migrants' family landholdings in the Anglo societies, but excluded migrants in the Hispanic Southern Cone.

Some of the first migrant wave to the Southern Cone in mid-century did manage to secure landholdings in areas such as the littoral of Uruguay, where they formed a (relatively) progressive class of pastoralists, but the interior of the pampas was locked into a large-landholding regime which was able to dictate terms to labour in a way that was not possible in the British dominions. This premature institutional closure of the land frontier condemned most migrants to wage labour or tenant status.

When meat exports boomed at the end of the nineteenth century in Argentina and Uruguay, the rural mode of production was non-capitalist in a completely different sense from that of dominion capitalism. In place of the family farm production system, the latifundio-minifundio system had been reproduced from elsewhere in Latin America. As technical change became increasingly important for agricultural and pastoral productivity growth in the twentieth century, the comparative performance of the two modes of production diverged markedly, as numerous commentators have remarked. ${ }^{46}$

The implication of this for convergence and divergence is that convergence in per capita income across countries by means of direct factor-price equalization, driven by international movement of labour and capital, depended on competitive conditions in the market for land. Therefore we could expect to see more evidence of convergence to the world core in the British colonies than in the Iberian settler economies.

\section{Stage Two: The staples export boom: trade-driven convergence}

The second great convergence force that can potentially drive factor-price equalization across the world system is commodity trade. Once processing and transportation technology advanced to the point where British consumers of wheat, meat, wool and dairy products could be supplied cost-effectively from the periphery, the settler economies found themselves located inside the extensive margin of wage-goods agriculture in the world core (Britain). In the technologically progressive cases, rapid adoption of productivityraising innovations placed settler producers inside the intensive margin as 
well. Both margins were located in Europe, where the prices of staples were set by the marginal product of capital and labour in home agriculture. Ricardian rents from the sale of staples at those prices flowed out to the settler economies, where they accrued to whichever groups had secured appropriation rights. Economic surplus flowed into settler economies, not out, making them in a sense 'exploiters' of the metropolis, not exploited by it. Here lies the key difference between the settler colonies and the tropical colonies of exploitation.

In terms of the economic theory of convergence, a set of export-driven economies selling the same commodities into a common core market at prices that yield Ricardian rents should tend to converge to a common level of per capita income, subject to two disturbing factors: the level of technology in staples production, and the institutional framework for domestic income distribution and resource allocation. With greater inequality in resource ownership and less aptitude for progressive technological innovation, the Hispanic settler economies could be expected to converge to a somewhat lower level than the dominion capitalisms, and this indeed seems to be what we can see in the data.

Belich $^{47}$ describes the export-led boom process as 'recolonization', and argues that settler dynamics involve well-defined stages that in some sense follow a logical sequence: first the boom of explosive colonization, then the bust as speculative bubbles collapse and intense pressure is put on the settlers' aspirations to high living standards, then a settler response in terms of 'export rescue' - the production of bulk staples for sale in outside markets, which provides a secure economic footing for the mature settler economy. But there is too much synchronicity in the great staples booms of the late nineteenth century to attribute them only to the internal dynamics of settler colonization. The world market for staple food and raw materials from the mid-nineteenth century was driven by the British economy. Without that world-system dimension, busted settler societies would have been faced with the need to rely on their own internal economic dynamics, which could not have produced the converged high-income success stories of 1900 (The exception to prove the rule is, of course, the USA, which indeed had its own internal capitalist dynamic and which had integrated its internal national market as effectively as Britain had integrated the global marketplace).

\section{The settler-economy golden age, 1890-1930}

Once established, the income relativities among the settler economies and between them and Britain have the appearance of a steady state lasting for three or four decades. Because there were increasing constraints on migration after 1914, it seems plausible that it was trade more than factor movements that played the key stabilizing role. 
During this period the sheer driving power of the staple-export sectors was extraordinary and opened up for all the settler societies the opportunity for innovative institutional and social reform. So long as the large rents from exports could be successfully recycled through the settler economy and society, they could sustain a raft of non-export activities and services, while providing the tax base for substantial redistributive institutions - 'battlismo' in Uruguay, and the nascent welfare state in Australia and New Zealand. A key structural feature of the rent-recycling process was the transmission channel through which rents entered the wider economy. In family-farm settler economies, the rents came into the hands of a relatively numerous and widely-dispersed class of independent farmers with a high propensity to spend on wage goods, services and inputs with a high local content, resulting in a relatively strong export multiplier for the local economy. In the Hispanic settler economies export rents tended to accrue to a narrower group with higher import propensities, so that the economy-wide income level sustained by a given volume of exports tended to be lower, and the potential importance of the state as an institutional mechanism to capture and allocate surplus was therefore greater. Largely for historic reasons, however, the Hispanic state tended to be weaker and less well-adapted for this purpose, partly because of the greater claim by the military on fiscal resources and partly because of the colonial heritage which weakened tax compliance and design.

Both Uruguay and New Zealand gained reputations as 'social laboratories' around the turn of the twentieth century, ${ }^{48}$ and as Lloyd ${ }^{49}$ observes of Australia,

The great wealth that flowed from rich primary exports underpinned [a] constitutional class compromise. Thus it was not despite but because of being a settler capitalist society that a social-democratic compromise could be developed and become so entrenched in the [subsequent] era of nascent industrialization. In turn, more or less complete industrialization was made possible by the central role of the social democratic state.

The two areas in which policy innovation related to export success was most obvious were the capture and redistribution of the economic surplus flowing from agrarian exports, and the development of institutional means of accelerating technological progress in the interests of greater productivity (and hence larger surplus). Farmer co-operatives, agricultural extension services, training schemes, technically-oriented publications for a literate farmer readership, and state involvement in the organization of single-desk marketing channels, were all common.

It was tight integration with the British market for agricultural and pastoral commodities that dragged all the settler economies, Hispanic as well as 
Anglo, into a common high-income band. For three or four decades the convergence forces held, during what could be termed the 'settler economy moment' of history. Then they let go, as the Great Depression and rising settler production collided to create gluts and falling prices in the UK market for meat, dairy products and wool. Suddenly the various settler countries were at loggerheads, competing to hold their places in an oversupplied market - a competition in which the British dominions came out on top at the Ottawa conference in 1932. The drama of Ottawa throws into stark relief a key feature of the preceding golden age, namely the relative lack of self-conscious competition amongst the settler economies prior to the Depression. Policy debates in New Zealand over Imperial Preference during the 1920s, for example, were dominated by the issue of non-British imports (especially Japanese goods) - not by competition for export markets. The settler economies were more like a co-operative cartel of suppliers to the booming UK market than a keenly-competing supply side. The bonanza, basically, was big enough to feed them all, and there was a great deal of mutual exchange of technical information and skilled labour amongst the settler economies, with the Hispanics fully incorporated into the information and factor-exchange networks. The onset of world market gluts broke these linkages and set the various countries onto separate paths.

\section{The great settler divergence}

There are five standard explanations for the parting of the ways among the settler economies after 1930:

- First is the different extent of progress in industrialization during the age of policy-driven import-substitution, 1930-1975. The USA was by 1930 already an established industrial power with a large enough domestic market to sustain heavy industry on a large scale, and the Second World War triggered a steep change in the level of US GDP relative to the rest (and to the UK). Among the other settler economies the ability to sustain an import-substituting industrialization programme was always constrained by the availability of export rents that could be redistributed via industrial wages and welfare-state arrangements. This was conditioned by export market access, by the effectiveness of policymaking, and by productivity and profitability in the export sectors. The Anglo economies secured a higher level of ongoing export rents, apparently more effective policy, and a more rapid rate of technical progress than the Hispanic economies, which accounts for the gradual widening of the gap during the 1950s and 1960s.

- Second, on the export front, the Great Depression brought far greater damage for Uruguayan and Argentine exports than for the British 
dominions because of the latter's ability to use Imperial Preference in their favour. At Ottawa, the political dimension of the world system abruptly came to the fore as Britain protected the access to its markets for meat and dairy products from the dominions and shut the Iberians out, apart from the beef quota allowed to Argentina under the 1933 Roca-Runciman pact. A similar negative trade shock struck New Zealand half a century later when Britain entered the European Economic Community.

- Third is the different institutional situation in the Anglo countries versus the Hispanic. In part, this was a matter of the legitimacy of government itself and hence its ability to implement effective policy, collect taxes and mediate social conflict. ${ }^{50}$ In part, it reflected different traditions between Hispanic and Anglo societies in matters such as political patronage and administrative practice. In part, it may also relate to the far greater political role of the military in Iberian as compared to Anglo settler states - notwithstanding the fact that the USA carries the largest and most costly military establishment of the eight.

- Fourth is the role of agrarian structure - the distribution of land and the strength of modernizing entrepreneurial groups in the sectors supplying staple export commodities. While modernizing elites are found in all the settler economies, they were more strongly evident in the Anglo economies than the Hispanics, with the result that agricultural productivity in the latter tended to lag - and with it the export rents.

- Fifth is the general issue of policy choices made by the ruling elites in the various settler economies. With hindsight it is common to criticize the detailed policies of, say, peronismo in Argentina as an 'explanation' for slower growth; but it can always be argued that the historic failure of peronismo was due as much to the fading momentum of Argentina's export economy, and consequent shrinkage of economic surplus relative to population. From the 1970 s on, all of the settler societies were conspicuous for their radical and ruthless adoption of neoliberal ideology - under authoritarian military control following the coups of 1973-5 in Uruguay, Chile and Argentina - but in no case did neoliberalism provide a growth panacea nor result in any revival of convergence amongst the economies.

All of these proposed lines of explanation suffer from the common failing that they look at relatively superficial proximate causes rather than at deep causes of long-run economic performance. Looking back to Figure 2, there seems to be a case for regarding the convergence process and the converged 'golden age' as an historical aberration - a temporary departure from divergent long-run growth paths which were already established by 
the middle of the nineteenth century. If this view is sustained, then the post-1930 divergence is not a puzzle at all, but simply the re-emergence of long-run trajectories that had been submerged or suppressed for four or five decades by world-system forces, but which reasserted themselves once the focus of the world system shifted in the Great Depression.

\section{Conclusion}

An important conclusion to emerge from this discussion is that the world system does embody strong convergence forces, which operate as mainstream theory suggests (through factor movements and international markets for traded goods), but that these forces are the dominant determinants of outcomes only in particular contingent situations (conjunctures). From time to time, global market forces throw up a 'convergence club' of countries that happen to share in some attribute or set of attributes that draw them through a convergence funnel into a corridor or 'corset' that can persist for some decades until a shift in the global conjuncture unlaces the corset, commonly in a dramatic event such as the Great Depression. The economies in the club then return to divergent growth paths based on longer-run historic trends rooted in the distant past, in response to forces operating over the very long run and inherent in the histories of individual economies and societies. World-system convergence forces, in other words, are powerful when they operate - but historically contingent as to when they operate on any particular set of economies, and always countervailed by historical path-dependence.

1 Lant Pritchett, Divergence, Big time: Background Paper for World Development Report 1995, World Bank Research Working Paper 1522, 1995; Lant Pritchett, 'Divergence Big Time', Journal of Economic Perspectives (JEP), 11, 3 (1997), pp.3-17; Angus Maddison, The World Economy: A Millennial Perspective, Paris: OECD, 2001, pp.46-48. Gregory Clark, A Farewell to Alms: A Brief Economic History of the World, New Jersey, 2007, Ch. 1; D. Acemoglu, S. Johnson, and J.A. Robinson, 'Reversals of Fortune: Geography and Institutions in the Making of the Modern World Income Distribution', Quarterly Journal of Economics, 117, 4 (2002), pp.1231-94.

2 The Hispanic cases had won nominal independence from Spain by the 1820s, but are often treated as part of Britain's 'informal empire' in the nineteenth century.

3 P. Ehrensaft and W. Armstrong, 'Dominion Capitalism: A First Statement', Australia and New Zealand Journal of Sociology, 14, 3, Part 2 (1978), pp.352-63; Warwick Armstrong, 'New Zealand: Imperialism, Class and Uneven Development', and 'Land, Class, Colonialism: the Origins of Dominion Capitalism', in W.E. Wilmott, ed., New Zealand and the World: Essays in Honour of Wolfgang Rosenberg, Christchurch, 1980.

4 Lists of their distinguishing features have been compiled by, for example, Donald Denoon, Settler Capitalism: The Dynamics of Dependent Development in the Southern Hemisphere, Oxford, 1984, pp.221-24; Ehrensaft and Armstrong, p.352; Richard Sutch, Toward a Unified Approach to the Economic History of Settler Economies, Keynote 


\section{Comparative Analysis of Settler Colonies}

Address, Asociación Uruguaya de Historia Económica (AUDHE), Montevideo, 2003, pp.7-10.

5 Maddison, World.

6 James Belich, Replenishing the Earth: The Settler Revolution and the Rise of the Anglo World, 1783-1939, Oxford, 2009.

7 Geoff Bertram, 'The New Zealand Economy, 1900-2000', in G. Byrnes, ed., The New Oxford History of New Zealand, Melbourne, 2009, pp.537-72.

8 Geoff Bertram, New, p.539, Figure 22.1.

9 John Kirby, 'On the Viability of Small Countries: Uruguay and New Zealand Compared', Journal of Inter-American Studies, 17 (1975), pp.259-80; D. Senghaas, The European Experience: A Historical Critique of Development Theory, trans. K.H. Kimmig, New Hampshire, 1985; M.H.J. Finch, A Political Economy of Uruguay since 1870, London, 1982.

10 Henry Willebald and Luís Bertola, 'Distribution, Specialization and Economic Performance in Settler Societies, 1870-2000', paper for XIV International Economic History Congress Helsinki-Finland, 21-25 August, 2006, www.helsinki.fi/iehc2006/ papers3/Bertola97.pdf.

11 Andrew Mitchell, 'Institutions and Factor Endowments: Income Taxation in Argentina and Australia', paper for XIVth International Economic History Congress, Helsinki, Finland, 21-25 August, 2006.

12 David Rock, Argentina 1516-1982: from Spanish colonization to the Falklands War, Berkeley, 1985, preface and pp.321-33.

13 Geoff Bertram, New, pp.539-540.

14 Kevin O'Rourke, Alan M. Taylor, and Jeffrey G Williamson, 'Factor Price Convergence in the Late 19th Century,' International Economic Review, 37, 3 (1996), pp.499-530.

15 David Ricardo, 'An Essay on the Influence of a Low Price of Corn on the Profits of Stock,' reprinted in P. Sraffa, ed., The Works and Correspondence of David Ricardo, Vol.4, 1951.

16 David Ricardo, 'On the Principles of Political Economy and Taxation,' reprinted in P. Sraffa, ed., The Works and Correspondence of David Ricardo, Vol.1, 1951.

17 John Stuart Mill, Principles of Political Economy with Some of their Applications to Social Philosophy, London, 1848.

18 Karl Marx, 'Manifesto of the Communist Party', translated S. Moore, in Karl Marx and Frederick Engels Selected Works Vol.1, Moscow, 1962, ch. 1.

19 Paul Baran, The Political Economy of Growth, New York, 1957.

20 Robert Solow, 'A Contribution to the Theory of Economic Growth', Quarterly Journal of Economics (QJE), 70 (1956), pp.65-94.

21 Robert E. Lucas, Jr, 'Why Doesn't Capital Flow from Rich to Poor Countries?', American Economic Review (AER), 80, 2 (1990), pp.92-96.

22 Pritchett, Divergence.

23 Moses Abramovitz, 'Catching Up, Forging Ahead and Falling Behind', Journal of Economic History (JEH) 46, 2 (1986), pp.385-406.

24 Walt W. Rostow, The Stages of Economic Growth: A Non-communist Manifesto, New York, 1960.

25 Robert E. Lucas, Jr, 'Some Macroeconomics for the Twenty-First Century', Journal of Economic Perspectives (JEP) 14, 1 (2000), pp.159-68. 


\section{Journal of New Zealand Studies}

26 D. Senghaas, The European Experience: A Historical Critique of Development Theory, trans. K.H. Kimmig, New Hampshire, 1985.

27 Denoon, p.221.

28 Denoon, p.221-24.

29 P. Ehrensaft and W. Armstrong

30 Robert E. Barro and Xavier Sala-i-Martin, Economic Growth, 1994, chs11 and 12.

31 P.A. Cashin, 'Economic Growth and Convergence Across the Seven Colonies of Australia: 1861-1991', The Economic Record (EC), 71, 213 (1995), pp.132-44.

32 David Greasley and Les Oxley, 'Growing Apart? Australia and New Zealand Growth Experiences, 1870-1993', New Zealand Economic Papers (NZEP), 33, 2 (1999), pp.114.

33 Geoff Bertram, 'On the Convergence of Small Island Economies with their Metropolitan Patrons', World Development (WD), 32, 2 (2004), pp.343-64.

34 Angus Maddison, Statistics on World Population, GDP and Per Capita GDP, 1-2006 $A D$, http://www.ggdc.net/maddison/historical_statistics/horizontal-file_03-2009.xls. 2009; plus 2007-2009 data from http://www.conference-board.org/data/economydatabase/

35 For a clear statement of this story, see Alan M. Taylor and Jeffrey G. Williamson, 'Capital Flows to the New World as an Intergenerational Transfer', Journal of Political Economy (JPE), 102, 2 (1994), pp.348-71.

36 Belich.

37 Denoon.

38 Alan M. Taylor and Jeffrey Williamson, 'Convergence in the Age of Mass Migration', European Review of Economic History (EREH), 1, 1 (1997), pp.27-63.

39 Belich, chs 5 and 6.

40 Taylor and Williamson, EREH, p.49.

41 Karl Marx, Capital Volume I, translated by Ben Fowkes, London, 1976, p.931, 933, 934, 935-6.

42 Finch, pp.5-7.

43 Rock, pp.xxvi-xxvii, 45-49, 119, 133-141.

44 Ibid: p.140.

45 Ibid: pp.141-2.

46 Kirby.

47 Belich.

48 Finch, ch. 1; Bronwyn Labrum, 'The Changing Meanings and Practices of Welfare', in G. Byrnes, ed. The New Oxford History of New Zealand, Melbourne, 2009, pp.397-406.

49 Christopher Lloyd, 'Australian and American Settler Capitalism: The Importance of a Comparison and its Curious Neglect', Australian Economic History Review (AEHR), 38, 3 (1998), p.297.

50 Mitchell. 